\title{
The differences in trigeminal system functional state in chronic and frequent migraine patients
}

\author{
G Pavlic $^{1 *}$, S Odobescu', I Moldovanu1', V Lacusta², L Rotaru', G Corcea' \\ From The European Headache and Migraine Trust International Congress \\ London, UK. 20-23 September 2012
}

\section{Introduction}

Electrophysiological tools like trigeminal somato-sensory evoked potentials (TSSEP) are used for evaluation of trigeminal system (TS) functional state. The activity of the later is an important factor in migraine pathogenesis. The study aim was to analyze the TS functional state in chronic and frequent migraine patients in relation with age during the migraine attack (critic period) and in the interictal period on lateralized stimulation (left/right).

\section{Results}

We have included 170 women with migraine (according to ICHD-IIR, 2006 criteria), between 15-55 years, 109chronic migraine (CM) and 61-frequent migraine (FM), mean age $38.3 \pm 10.7$ and $36.5 \pm 9.1$ years, respectively. In $C M$ vs. FM patients aged $15-25$ years a statistic significant reduction in wave latencies $\mathrm{N} 15$ ( $15.4 \pm 0.47$ vs. 17.67 $\pm 0.42, \mathrm{p}<0.01)$, P22 (22.24 \pm 0.69 vs. $25.11 \pm 0.73, \mathrm{p}<0.05)$, interval N6-P9 $(3.56 \pm 0.29$ vs. $5,11 \pm 0.56, \mathrm{p}<0.05)$ on the left side and of intervals N6-P9 ( $3.28 \pm 0.40$ vs. $5.36 \pm 0.54$, $\mathrm{p}<0.05)$ and N6-P22 (16.76 \pm 0.52 vs. $19.18 \pm 0.80, \mathrm{p}<0.05)$ on the right was observed, but not in other age groups. Reduced latency and shorter conduction time at nuclearthalamic level (interval N6-P9) might reflect an increased excitability of thalamic and cortical structures (P22) of trigeminal sensory complex in young patients. There were no differences in TSSEP in CM vs. FM during a migraine attack.

\section{Conclusions}

Functional disturbances in trigeminal system in chronic migraine vs. frequent migraine might be seen in young patients based on latencies of TSSEP and on central time of the somatosensory trigeminal transmission. These changes

Institute of Neurology and Neurosurgery, Moldova, Republic of

Full list of author information is available at the end of the article might reflect a different activity of brainstem-diencephalic (thalamic) structures.

\section{Author details}

'Institute of Neurology and Neurosurgery, Moldova, Republic of. ${ }^{2}$ State Medical and Pharmaceutical University, Moldova, Republic of.

Published: 21 February 2013

Reference

1. Ambrosini A, de Noordhout AM, Sándor PS, Schoenen J:

Electrophysiological studies in migraine: a comprehensive review of their interest and limitations. Cephalalgia 2003, 23(Suppl. 1):13-31.

doi:10.1186/1129-2377-14-S1-P125

Cite this article as: Pavlic et al:: The differences in trigeminal system functional state in chronic and frequent migraine patients. The Journal of Headache and Pain 2013 14(Suppl 1):P125.

\section{SpringerOpen ${ }^{\circ}$}

(0) 2013 Pavlic et al; licensee Springer. This is an Open Access article distributed under the terms of the Creative Commons Attribution License (http://creativecommons.org/licenses/by/2.0), which permits unrestricted use, distribution, and reproduction in any medium, provided the original work is properly cited.
Submit your manuscript to a SpringerOpen ${ }^{\circ}$ journal and benefit from:

- Convenient online submission

- Rigorous peer review

- Immediate publication on acceptance

- Open access: articles freely available online

- High visibility within the field

- Retaining the copyright to your article

Submit your next manuscript at $\gg$ springeropen.com 